\title{
Dowex 50W: A Green Mild Reusable Catalyst for the Synthesis of 2-Aryl Benzoxazole Derivatives in Aqueous Medium
}

\author{
ARUP DATTA \\ Department of Chemistry, Shibpur Dinobundhoo Institution (College), 412/1, G. T. Road (South), \\ Howrah-711102, West Bengal, India. \\ *Corresponding author E-mail: arupdattadb @gmail.com \\ http://dx.doi.org/10.13005/ojc/370211
}

(Received: February 15, 2021; Accepted: March 17, 2021)

\section{ABSTRACT}

In this work simple efficient, one pot and environmentally friendly method was developed for the synthesis of 2-Aryl-1H-benzoxazole derivatives at $80^{\circ} \mathrm{C}$ using ortho-aminophenol and various aldehydes. It has been found that Dowex $50 \mathrm{~W}$ is an effective catalyst to prepare moderate to high yield of a variety of benzoxazole derivatives through a clean and simple process. Aqueous medium, green methodology, rapid reaction, reusability of heterogeneous catalyst are the great advantages of this protocol.

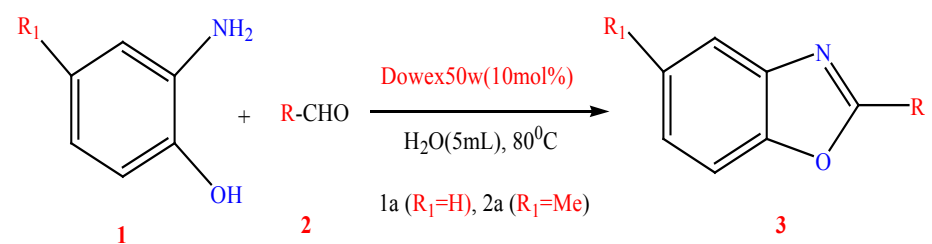

Keywords: Benzoxazole, Aqueous medium, Heterogeneous catalyst, Dowex 50W, Reusable catalyst.

\section{INTRODUCTION}

2-Substituted benzoxazole derivatives are the main structural features and have immense interest in biologically active pharmaceutical chemistry such as 5 -HT3 receptor agonist ${ }^{1}$, melatonin ${ }^{2}$, VLA-4 antagonist ${ }^{3}$ like imidazole ${ }^{3}$ and benzimidazole ${ }^{3}$. Benzoxazole derivatives are used as inhibitors against different enzymes in the pathophysiology of various diseases for example manopeptimycin glycopeptides antibiotics $^{4}$, antimicrobial ${ }^{5}$, antimycobacterial ${ }^{6}$ anticancer ${ }^{7}$ and antitumor agents ${ }^{8}$. It is also used as a amyloidogenesis inhibitors ${ }^{9}$, Rho kinase inhibitors ${ }^{10}$, HIV-1 reverse transcriptase ${ }^{11}$, fructose1,6-bisphosphatase ${ }^{12}$, cyclooxygenase ${ }^{13}$, LPAAT- $\beta^{14}$, elastase $^{15}$. Benzoxazole derivatives are used as a scaffold in fluorescent probes ${ }^{16}$ metal ion sensors and also in photochromatic reagent ${ }^{17}$ and laser dyes $^{18}$. In addition benzoxazoles are the main class of heterocycles which are used for the construction of natural products and these are extensively applied in drug discovery and in an agrochemical field. This

This is an Open Access article licensed under a Creative Commons license: Attribution 4.0 International (CC- BY). Published by Oriental Scientific Publishing Company @ 2018

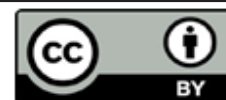


moiety is also found in cytotoxic natural products like AJI9561 ${ }^{19}$, UK-1 ${ }^{20}$ and salvianen ${ }^{21}$. In recent published papers shown that it is involved in selective peroxisome proliferator-activated receptor $\gamma$ antagonist JTP-42646722 and the cathepsin S inhibitor ${ }^{23}$. These make it interesting to synthesize 2-substituted benzoxazole derivatives in a new synthetic way. Usually two processes are applied for the synthesis of benzoxazole derivatives where common substrate was ortho-aminophenol ${ }^{24}$. (a) The traditional method is the condensation of ortho-aminophenol with acid or its derivative like acyl chlorides in strong acid medium like PPA, boric acid glycerol, silica sulfuric acid ${ }^{28}$, methanesulphonic acid ${ }^{29}, \mathrm{p}-\mathrm{TsOH}^{34}, \mathrm{BF}_{3} . \mathrm{OEt}_{2}{ }^{32}$ either at high temperature ${ }^{25}$ or with microwave-assisted reaction conditions ${ }^{26}$. There is too much interest in making this compound and that's why various methodologies and various oxidative catalysts were applied to conduct the synthesis of these derivatives till now ${ }^{26}$. (b) The second method is the cyclisation through condensation of intermediate imine ${ }^{27}$ formation then oxidation by use of different solid based catalysts such as PCC-supported silica gel ${ }^{30}$, silica supported sodium hydrogen sulfate ${ }^{31}$, ([Hbim] $\mathrm{BF} 4)^{33}$, pyridinium-p-toluenesulfonate ${ }^{35}$ and this methods have many advantages over unsupported catalyst such as environmentally benign easy work up, clean reaction protocol, high yield process. Few toxic transition metal catalysts were used such as $\mathrm{NiO}_{2}{ }^{36}$, $\ln (\mathrm{OTf})_{3}{ }^{37}, \mathrm{Cu}(\mathrm{OTf})_{2}{ }^{38}, \mathrm{Mn}(\mathrm{OAc})_{3}{ }^{39}, \mathrm{~Pb}(\mathrm{OAc})_{4}{ }^{40}, \mathrm{ZrOCl}_{2}$ $8 \mathrm{H}_{2} \mathrm{O}^{41}, \mathrm{CeCl}_{3}{ }^{42}$ for the synthesis of the benzoxazole derivatives with good yield. However, in most case there was some drawback like (a) strong acid used either in solvent free condition or conventional heating or microwave heating ${ }^{28-31}$; (b) complex workup procedure has been employed ${ }^{39}$; (c) requirement of toxic, hazardous, expensive reagents and catalysts for excellent conversion ${ }^{43}$; (d) long reaction time was observed to complete the reaction in few cases ${ }^{44}$ and (e) in some cases comparatively low yield was observed in rapid reaction ${ }^{44}$. So an efficient and Eco-friendly process is still required for the synthesis of 2-arylbenzoxazole derivatives.

\section{RESULTS AND DISCUSSIONS}

In this work, author reports a very effective and easy method for the preparation of 2-aryl-1H-benzoxazole by condensation reaction of aldehydes with substituted and unsubstituted ortho-aminophenol in presence of heterogeneous catalyst Dowex $50 \mathrm{~W}$ at $80^{\circ} \mathrm{C}$.

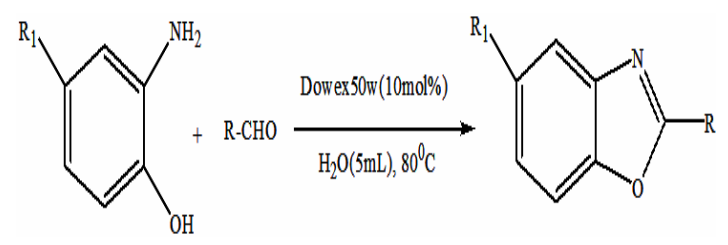

Scheme 1. Synthesis of 2-Aryl substituted benzoxazole in presence of Dowex 50W

Keeping in mind the sustainability of the environment the conversion of organic reaction in water has been given greater importance now a day's. Water acts as an environmentally benign solvent ${ }^{45}$. Water shows physiochemical properties, including hydrophobic molecular association activity, large thermal capacity, high polarity, inter molecular hydrogen bonding ability. Because of this distinct advantages of water both the effectiveness of the catalyst and the rate of the reaction increases in organic transformation. This catalyst is environmentally benign and has been getting attractive interest in synthetic research chemistry ${ }^{45 a}$. In earlier reported procedure this catalyst (sulphonic acid based cation exchange resin) was successfully applied to synthesis 2-arylsubstituted$1 \mathrm{H}$-benzimidazoles ${ }^{45 b}$, 2-substituted benzothiazole derivatives $^{45 c}$ and quinoxaline derivatives ${ }^{45 d}$ with excellent yield in aqueous medium. So to explore new synthetic green methodology author used Dowex 50W as a source of acid catalyst resin in the formation of benzoxazole derivatives in aqueous medium.

Table 1: Solvent effect and catalyst activity for the synthesis of 2-arylsubstitutedbenzoxazole

\begin{tabular}{|c|c|c|c|c|c|}
\hline Entry & $\begin{array}{c}\text { Dowex 50W } \\
(\mathrm{mol} \%)\end{array}$ & ${ }^{\mathrm{a} C o n d i t i o n s}$ & $\begin{array}{c}\text { Solvent } \\
(5 \mathrm{~mL})\end{array}$ & $\begin{array}{l}\text { Time } \\
\text { (mins) }\end{array}$ & $\begin{array}{c}{ }^{\text {bYield }} \\
(\%)\end{array}$ \\
\hline 1 & 0 & Oil bath, $80^{\circ} \mathrm{C}$ & water & 210 & 0 \\
\hline 2 & 5 & Oil bath, $80^{\circ} \mathrm{C}$ & water & 210 & 65 \\
\hline 3 & 10 & Oil bath, $80^{\circ} \mathrm{C}$ & water & 210 & 90 \\
\hline 4 & 10 & Oil bath, $90^{\circ} \mathrm{C}$ & water & 210 & 90 \\
\hline 5 & 15 & Oil bath, $80^{\circ} \mathrm{C}$ & water & 210 & 90 \\
\hline 6 & 15 & Oil bath, $90^{\circ} \mathrm{C}$ & water & 210 & 89 \\
\hline 7 & 20 & Oil bath, $80^{\circ} \mathrm{C}$ & water & 210 & 90 \\
\hline 8 & 25 & Oil bath, $80^{\circ} \mathrm{C}$ & water & 210 & 90 \\
\hline 9 & 30 & Oil bath, $80^{\circ} \mathrm{C}$ & water & 210 & 90 \\
\hline 10 & 10 & Oil bath, $80^{\circ} \mathrm{C}$ & $\mathrm{EtOH}$ & 210 & 50 \\
\hline 11 & 10 & Oil bath, $80^{\circ} \mathrm{C}$ & $\begin{array}{c}\text { Aqueous } \\
\mathrm{EtOH}\end{array}$ & 210 & 55 \\
\hline 12 & 10 & Oil bath, $80^{\circ} \mathrm{C}$ & $\mathrm{MeCN}$ & 210 & 45 \\
\hline 13 & 10 & Oil bath, $80^{\circ} \mathrm{C}$ & DMSO & 210 & 38 \\
\hline 14 & 10 & Oil bath, $80^{\circ} \mathrm{C}$ & THF & 210 & 35 \\
\hline 15 & 10 & Oil bath, $80^{\circ} \mathrm{C}$ & Neat & 210 & 48 \\
\hline
\end{tabular}

aReaction condition:2-aminophenol (1.2 mmol), p-chlorobenzaldehyde (1mmol), ' Isolated yield 
2-Aminophenol (1.2mmol) and 4-chlorobenzaldehyde $(1 \mathrm{mmol})$ were taken as substrates to find out the optimization condition. From Table 1 it was clear that in water alone zero percent yield of the product was noticeable without any catalyst (Entry 1 , Table 1). Only $65 \%$ yield of the product was obtained in presence of $5 \mathrm{~mol} \%$ of Dowex 50W (Entry 2, Table 1) and percentage of the product yield was increased to $90 \%$ when $10 \mathrm{~mol} \%$ catalyst was applied (Entry 3, Table 1). Even in presence of more than $10 \mathrm{~mol} \%$ of the catalyst no change was found in \%yield of the product (Entry 5, Table 1). More over at slightly higher temperature at $90^{\circ} \mathrm{C}$ no improved yield was observed (Entry 6, Table 1). So author came to the conclusion that $10 \mathrm{~mol} \%$ of the catalyst was sufficient to complete the reaction and it had been proved in earlier published paper ${ }^{45 a, d}$ also. It was found that in ethanol and aqueous ethanol the yield were moderate but poor yield was observed in
THF, DMSO, MeCN and in solvent free condition. So standard reaction condition was accurately investigated and it was represented in (Entry 3, Table 1). In Fig. 1 author has shown clearly the relevance of catalyst in this methodology.

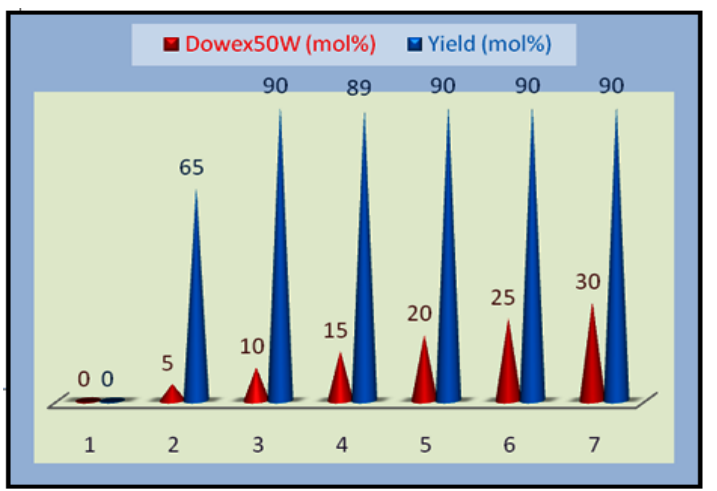

Fig. 1. Graphical representation of the effect of the mol\% of catalyst against \%isolated yield of product (Table 2, 3f)

Table 2: Synthesis of 2-Aryl-1H-benzoxazole derivatives catalyzed by $10 \mathrm{~mol} \%$ Dowex $50 \mathrm{~W}$ in aqueous medium at $80^{\circ} \mathrm{C}$

\begin{tabular}{|c|c|c|c|c|c|c|c|}
\hline \multirow[t]{2}{*}{ Entry } & \multirow[t]{2}{*}{ Aminophenol $\left(R_{1}\right)[1]$} & \multirow[t]{2}{*}{ Aldehyde(R) [2] } & \multirow[t]{2}{*}{ Benzoxazole[3] } & \multirow[t]{2}{*}{ Time (mins) } & \multirow[t]{2}{*}{ Isolated Yield(\%) } & \multicolumn{2}{|c|}{$\operatorname{MP}\left({ }^{\circ} \mathrm{C}\right)$} \\
\hline & & & & & & Found & Literature \\
\hline 1 & $1 a$ & $\mathrm{C}_{6} \mathrm{H}_{5}$ & $3 a$ & 180 & 90 & 102-104 & $102-104^{45}$ \\
\hline 2 & $1 a$ & 2-Me- $\mathrm{C}_{6} \mathrm{H}_{4}$ & $3 b$ & 240 & 88 & 116 & $114-116^{46}$ \\
\hline 3 & $1 \mathrm{a}$ & 4-Me- $\mathrm{C}_{6} \mathrm{H}_{4}$ & $3 c$ & 240 & 85 & 113-114 & $113-114^{45}$ \\
\hline 4 & $1 \mathrm{a}$ & $2-\mathrm{OMeC}_{6} \mathrm{H}_{4}$ & $3 d$ & 270 & 85 & 54 & $53-55^{47}$ \\
\hline 5 & $1 a$ & $4-\mathrm{OMeC}_{6} \mathrm{H}_{4}^{4}$ & $3 e$ & 300 & 88 & 98 & $98^{44}$ \\
\hline 6 & $1 a$ & $4-\mathrm{Cl}-\mathrm{C}_{6} \mathrm{H}_{4}{ }^{4}$ & $3 f$ & 210 & 90 & 150 & $148-150^{48}$ \\
\hline 7 & $1 a$ & $2-\mathrm{Cl}-\mathrm{C}_{6} \mathrm{H}_{4}^{4}$ & $3 g$ & 180 & 88 & $62-64$ & $61-64^{49}$ \\
\hline 8 & $1 \mathrm{a}$ & 4-F- $\mathrm{C}_{6}^{6} \mathrm{H}_{4}^{4}$ & $3 \mathrm{~h}$ & 240 & 90 & 100 & $99-100^{50}$ \\
\hline 9 & $1 a$ & $4-\mathrm{NO}_{2}-\mathrm{C}_{6} \mathrm{H}_{4}$ & $3 i$ & 210 & 88 & 156 & $156-157^{49}$ \\
\hline 10 & $1 \mathrm{a}$ & $3-\mathrm{OMeC}_{6} \mathrm{H}_{4}^{4}$ & $3 j$ & 240 & 90 & $108-109$ & $107-109^{51}$ \\
\hline 11 & $1 \mathrm{a}$ & 2-Furanyl & $3 \mathrm{k}$ & 240 & 85 & 90 & $90-92^{45}$ \\
\hline 12 & $1 \mathrm{a}$ & $4-\mathrm{Br}-\mathrm{C}_{6} \mathrm{H}_{4}$ & 31 & 210 & 89 & 158 & $157-158^{52}$ \\
\hline 13 & $1 a$ & $4-\mathrm{CN}-\mathrm{C}_{6}^{6} \mathrm{H}_{4}^{4}$ & $3 m$ & 240 & 90 & 204 & $203-206^{53}$ \\
\hline 14 & $1 a$ & $3-\mathrm{Cl}-\mathrm{C}_{6} \mathrm{H}_{4}{ }_{4}$ & $3 n$ & 210 & 88 & 132 & $131-133^{48}$ \\
\hline 15 & $1 a$ & 2-Thienyl & 30 & 250 & 82 & 104-106 & $104-106^{45}$ \\
\hline 16 & $1 a$ & 2-Cinnamyl & $3 p$ & 210 & 86 & 80 & $79-80^{54}$ \\
\hline 17 & $1 a$ & $2-\mathrm{Br}-\mathrm{C}_{6} \mathrm{H}_{4}$ & $3 q$ & 180 & 87 & $54-55$ & $54-55^{55}$ \\
\hline 18 & $2 a$ & 4-Me- $\mathrm{C}_{6} \mathrm{H}_{4}^{4}$ & $3 r$ & 210 & 88 & 138 & $138-139^{56}$ \\
\hline 19 & $2 a$ & $4-\mathrm{Cl}-\mathrm{C}_{6} \mathrm{H}_{4}$ & $3 s$ & 230 & 85 & 150 & $150-151^{56}$ \\
\hline 20 & $2 a$ & $\mathrm{C}_{6} \mathrm{H}_{5}$ & $3 t$ & 240 & 86 & 114 & $112-115^{56}$ \\
\hline
\end{tabular}

Receiving the actual reaction condition then it was successfully applied to form a range of other benzoxazole derivatives. 2-Aminophenol and variety of aromatic aldehydes and hetero aldehydes were used under the chosen reaction condition and all cases the reactions were clean and highly selective to generate good to excellent yield in a very short reaction time and results were summarized in Table 2. Addition, cyclisation followed by oxidation reaction readily took place between aldehyde and 2 -aminophenol at $80^{\circ} \mathrm{C}$. Yields of benzoxazole were slightly affected by electronic factor and as well as steric factor. Electron withdrawing groups present in an aromatic ring generates good yield of the benzoxazole derivatives because these groups increase the electrophilicity of the aldehyde moiety (Entries 8, 9 13, Table 2). Electron releasing $o$-substituted aldehyde gave slight poor yield than 
meta or para substitution present in aromatic ring (Entries 4 and 7, Table 2). In this methodology Dowex 50W catalyst act as a Brønsted acid which actually increases the electrophilic nature of the carbonyl carbon by coordination and as a result nucleophilic attack by nitrogen centre to the carbonyl carbon took place rapidly. The reaction between an aldehyde and 2-aminophenol proceed through the condensation reaction mechanism, which results in the formation of a Schiff base and then oxidative cyclization reaction took place ${ }^{57}$. Author has also studied one reaction in inert atmosphere like (argon atmosphere) but low yield of the product was observed which indicated that aerial oxygen was essential to complete the last step of oxidation. The plausible reaction mechanism of benzoxazole derivative is given in Scheme 2.

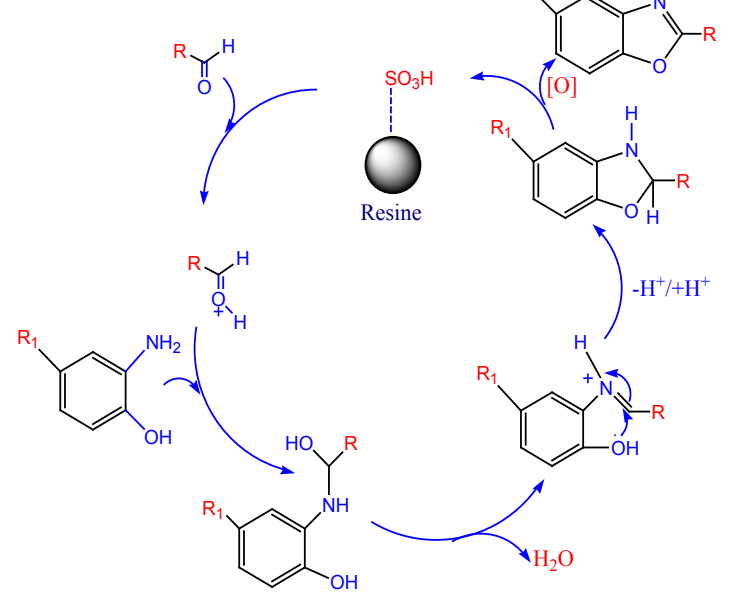

Scheme 2. Plausible reaction mechanism of 2-Aryl benzoxazole derivatives

Recycling of catalyst is very important in organic transformation and as well as in industrial purpose. So recycle activity of the catalyst studied in this reaction. After the completion of the reaction the product was extracted with warm ethanol and filtered to eliminate the Dowex $50 \mathrm{~W}$.

Then recovered catalyst was purified with ethanol to remove adhering product and dried in vacuum. The recovered catalyst was reused in the next reaction. Experimental result indicates that no loss of catalytic efficacy in consecutive four time runs of the catalyst and it clearly displayed graphically in Figure 2.

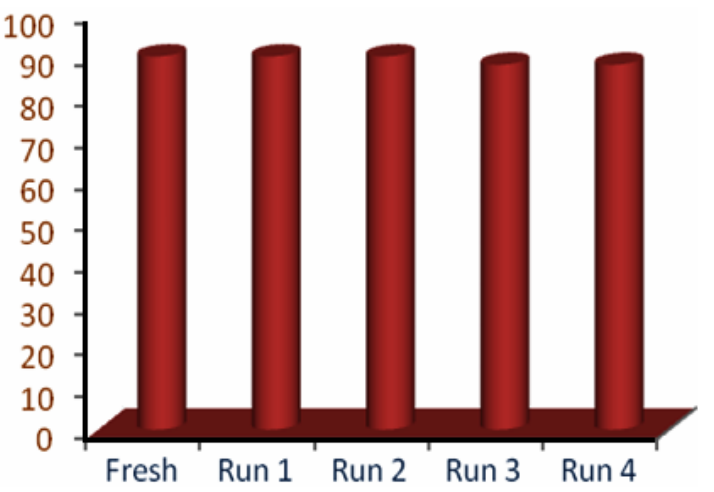

Fig. 2. Graphical representation of reusability test of the catalyst Dowex 50W (Table 2, 3f)

Table 3: Comparison of the catalyst used in previously published papers for the formation of 2-(4'-chlorophenyl)-1H-benzoxazole

Entry Catalyst Time Isolated Temperature Reference (h) Yield $(\%) \quad\left({ }^{\circ} \mathrm{C}\right)$

\begin{tabular}{lccccc}
\hline 1 & $\begin{array}{c}\text { Molecular } \\
\text { Sieve }\end{array}$ & 48 & 85 & $180-190$ & 58 \\
2 & $\mathrm{Zn}(\mathrm{OTf})_{2}$ & 5 & 89 & Reflux & 59 \\
3 & $\mathrm{MeSO}_{3} \mathrm{H}$ & 2 & 70 & 100 & 60 \\
4 & $\mathrm{CeCl}_{3} / \mathrm{Nal}$, & 36 & 80 & 100 & 61 \\
5 & $\mathrm{Ni}^{-S i O}{ }_{2}$ & 2.5 & 88 & Room temp & 62 \\
6 & Dowex 50W & 3.5 & 90 & 80 & Present Work \\
\hline
\end{tabular}

The effeciency of different catalysts in the synthesis of 2-(4'-chlorophenyl)-1 $\mathrm{H}$ benzoxazole has been compared with some previously published papers shown in Table 3. Comparison with respect to time and yield the present reaction methodology is excellent in presence of heterogenous catalyst Dowex $50 \mathrm{~W}$. The advantages of the present reaction procedures are as follows; (a) In present methodology no additive expensive toxic oxidizing reagent was required. (b) This catalyst acts as an environmentally benign green catalyst because the reaction was performed in aqueous medium to avoid the use of toxic, hazardous organic solvents. (c) To complete the reaction only 10 mol\% of catalyst was sufficient to generate excellent yield of the products. (d) The catalyst was recycled four times without any loss of efficacy. (f) A series of 2-arylbenzoxazole was prepared containing different groups at different positions with different electronic behavior in aromatic aldehyde ring. (g) Workup procedure was so simple no need of hectic column chromatography. (h) The amount of the product can be increased in large scale. 


\section{EXPERIMENTAL}

All aromatic aldehydes and orthoaminophenol were purchased from Spectrochem, Pvt. Ltd. Mumbai, India. ${ }^{1} \mathrm{H}$ and ${ }^{13} \mathrm{C}$ NMR spectra and IR spectra were recorded on Bruker $300 \mathrm{MHz}$ spectrometer and Perkin-Elmer spectrometer. $\mathrm{CDCl}_{3}$ and DMSO- $d_{6}$ are used as solvents. Melting points were measured with electrical apparatus. Reactions were monitored by thin-layer chromatography (TLC) on glass sheets pre-coated with silica gel.

\section{General Procedure}

A mixture of Substituted benzaldehyde $(1 \mathrm{mmol})$ with ortho-aminophenol $(1.2 \mathrm{mmol})$, Dowex $50 \mathrm{~W}$ (10 mol\%) were mixed in a $50 \mathrm{~mL}$ round bottom flask and it was heated in an oil bath at $80^{\circ} \mathrm{C}$. The reaction was monitored by TLC time to time. Completion of the reaction was indicated by the brown spot which was developed in an iodine chamber. The crude product was cooled and diluted with warm ethanol and filtered. Then it was concentrated and the catalyst was washed again with warm ethanol to eliminate product attached on the surface of the catalyst. The catalyst was reused in the next reaction under the same reaction condition. The product was crystallized directly from hot aqueous ethanol to produce the pure 2-substituted benzoxazoles with $82-90 \%$ yield. All the known compounds were characterized by comparing their physical and spectral data with authentic compounds.

\section{Spectroscopic data of synthesized compound 2-Phenyl-1H-benzoxazole (Table 2, 3a)}

Colourless solid; FT-IR $\left(\mathrm{KBr}, \mathrm{cm}^{-1}\right)$ : 1240 , 1285, 1448, 1475, 1551, 1615, 1775, 2854, 2925 and 3059, ${ }^{1} \mathrm{H}$ NMR $\left(300 \mathrm{MHz}, \mathrm{CDCl}_{3}\right)$ 8: 7.40-7.33 $(\mathrm{m}, 2 \mathrm{H}), 7.55-7.50(\mathrm{~m}, 3 \mathrm{H}), 7.61-7.56(\mathrm{~m}, 1 \mathrm{H})$, , 7.82$7.75(\mathrm{~m}, 1 \mathrm{H}), 8.31-8.22(\mathrm{~m}, 2 \mathrm{H}),{ }^{13} \mathrm{C}$ NMR $(75 \mathrm{MHz}$, $\left.\mathrm{CDCl}_{3}\right) \delta: 110.7,120 ., 124.7,125.3,127.3,127.8$, 129.0, 131.7, 142.2, 150.9 and 163.2, Analytical Calculation for $\mathrm{C}_{13} \mathrm{H}_{9} \mathrm{NO}: \mathrm{C}: 79.98 ; \mathrm{H}: 4.65 ; \mathrm{N}: 7.17 \%$; Found: C: $79.81 ; \mathrm{H}: 4.51 ; \mathrm{N}: 7.09 \%$.

\section{2-(4'-chlorophenyl)-1H-benzoxazole (Table 2, 3f)}

Colourless solid; FT-IR $\left(\mathrm{KBr}, \mathrm{cm}^{-1}\right)$ : 740,1091,1246,1439, 1620 and 2962, ${ }^{1} \mathrm{H}$ NMR (300 $\left.\mathrm{MHz}, \mathrm{CDCl}_{3}\right) \delta$ 7.27-7.31 (m, 2H); 7.41-7.45 (m, 2H); 7.50-7.54 (m, 1H); 7.67-7.71 (m, 1H); 8.11-8.14 (m, 2H) ${ }^{13} \mathrm{C} \mathrm{NMR}\left(75 \mathrm{MHz}, \mathrm{CDCl}_{3}\right) \delta 110.0,120,124.8,125.2$, 125.9, 128.6, 130, 129, 129.2, 137.8, 141.8, 150.8, 161.9. Analytical Calculation for $\mathrm{C}_{13} \mathrm{H}_{8} \mathrm{CINO}$ : C: 67.99 ; $\mathrm{H}: 3.51 ; \mathrm{N}: 6.10 \%$. Found: C: $67.75 ; \mathrm{H}: 3.45 ; \mathrm{N}: 5.96 \%$.

\section{CONCLUSION}

Author reported highly efficient synthetic protocol for the development of benzoxazole derivatives in presence of Bronsted acid catalyst Dowex 50W. The reaction gets another dimension because of rapid Eco-friendly reaction, simple workup procedure, avoiding toxic, hazardous organic solvents and reusability of the catalyst. It is hope that in near future this reaction will dominate academically and industrially.

\section{ACKNOWLEDGEMENT}

I am very much grateful to my $\mathrm{Ph}$.D supervisor Professor Chhanda Mukhopadhyay, Department of Chemistry, University of Calcutta for providing me laboratory facility and financial support.

\section{Conflict of Interest}

No conflict of interest regarding this article.

\section{REFERENCES}

1. López-Tudanca, P. L.; Labeaga, L.; Innerárity, A.; Alonso-Cires, L.;Tapia, I.; Mosquera, R.; Orjales, A.; Bioorg. Med. Chem., 2003, 11, 2709-2714.

2. Sun, L. Q.; Chen, J.; Takaki, K.; Johnson, G.; Iben, L.; Mahle, C. D.; Ryan, E.; Xu, C.; Bioorg. Med. Chem. Lett., 2004, 14, 1197-2200.

3. (a) Lin, L. S.; Lanza, T. Z.; Castonguay, L. A.; Kamenecka, J. T.; McCauley, E.; Riper, G. V.; Egger, L. A.; Mumford, R. A.; Tong, X.; MacCoss, M.; Schmidt, J. A.; Hagmann, W. K.; Bioorg. Med. Chem. Lett., 2004, 14(9), 2331- 2334.(b) Tayebee, R.; Gohari, A.; Eura. chem. Com., 2020, 2(5), 581-586. (c) Tayebee, R.; Abdizadhe, M. F.; Arfaninia, N.; Amiri, A.; Baghayeri, M.; Kakhki, R. M.; Maleki, B.; Esmaili, E.; Appl. Organomet. Chem., 2019, 33(8), 1-10. (d) Maleki, B.; Eshghi, H.; Khojastehnezhad, A.; Tayebee, R.; Ashrafi, S. S.; Kahoo, G .E.; Moeinpour, F.; RSC Adv., 2015, 5, 64850-64857. (e) Li, B.; Tayebee, R.; Esmaeili, E.; Namaghi, M. S.; Maleki, B.; RSC Adv., 2020, 10, 40725-40738. 
4. Vinsova, J.; Cermakova, K.; Tomeckova, A.; Ceckova, M.; Jampilek, J.; Cermak, P.; Kunes, J.; Dolezal, M.; Staud, F.; Bioorg. Med. Chem., 2006, 14(17), 5850-5865.

5. Yildiz-Oren, L.; Yalcin, I.; Aki-sener, E.; Ucarturk, N.; Eur. J. Med. Chem., 2004, 39, 291-298.

6. Rodríguez, I. I.; Rodríguez, A. D.; Wang, Y.; Franzblau, S. G.; Tetrahedron Lett., 2006, 47, 3229-3232.

7. Huang, S.T.; Hsei, I. J.; Chen, C.; Bioorg. Med. Chem., 2006, 14, 6106-6119.

8. (a) Kumar, D.; Jacob, M. R.; Reynolds, M. B.; Kerwin, S. M.; Bioorg. Med. Chem., 2002, 10, 3997-4004. (b) Rida, S.M.; Ashour, F. A.; ElHawash, S. A. M.; ElSemary, M. M.; Badr, M. H.; Shalaby, M. A. Eur. J. Med. Chem., 2005, 40, 949-595.

9. Johnson, S. M.; Connelly, S.; Wilson, I. A.; Kelly, J. W.; J. Med. Chem., 2008, 51, 260270.

10. Sessions, E. H.; Yin, Y.; Bannister, T. D.; Weiser, A.; Griffin, E.; Pocas, J.; Cameron, M. D.; Ruiz, C.; Lin, L.; Schuerer, S. C.; Schroeter, T.; LoGrasso, P.; Feng, Y. Bioorg. Med. Chem. Lett., 2008, 18, 6390-6393.

11. Medebielle, M.; Ait-mohand, S.; Burkhloder, C.; Dolbier, W. R.; Laumond, G.; Aubertin, A. M.; J. Fluor. Chem., 2005, 126, 533-540.

12. Lai, C.; Gum, R.J.; Daly, M.; Fry, E.H.; Hutchins, C.; Abad-Zapatero, C.; Von Geldern, T.W.; Bioorg. Med. Chem. Lett., 2006, 16, 18071810.

13. Paramashivappa, R.; Kumar, P. P.; Subba, R. P. V.; Srinivasa, R. A.; Bioorg. Med. Chem. Lett., 2003, 13, 657-660.

14. Gong, B.; Hong, F.; Kohm, C.; Bonham, L.; Klein, P.; Bioorg. Med. Chem.Lett., 2004, 14, 1455-1459.

15. Edwards, P. D.; Meyer, E. F.; Vijayalakshmi, J. J.; Tuthill, P. A.; Andisik, D. A.; Gomes, B.; Strimpler, A.; J. Am. Chem. Soc., 1992, 114, 1854-1863.

16. Hein, D. W.; Alheim, R. J.; Leavitt, J. J. J. Am. Chem. Soc., 1957, 79, 427-429.

17. Sum, P. E.; How, D.; Torres, N.; Newman, H.; Petersen, P. J.; Mansour, T. K.; Bioorg. Med. Chem. Lett., 2003, 13, 2607-2625.

18. Heynderickx, A.; Guglielmetti, R.; Dubest, R.; Aubard, J.; Samat, A.; Synt., 2003, 1112-
1116.

19. Sato, S.; Kajiura, T.; Noguchi, M.; Takehana, K.; Kobayashi, T.; Tsuji, T.; J. Antibiot., 2001, 54, 102-104.

20. Ueki, M.; Ueno, K.; Miyadoh, S.; Abe, K.; Shibata, K.; Taniguchi, M.; Oi, S. J. Antibiot., 1993, 46, 1089.

21. Don, M. J.; Shen, C. C.; Lin, Y. L.; Syu, J. RW.; Ding, Y. H.; Sun, C. M.; J. Nat. Prod., 2005, 68, 1066-1070.

22. Nishiu, J.; Ito, M.; Ishida, Y.; Kakutani, M.; Shibata, T.; Matsushita, M.; Shindo, M. Diabetes Obes. Metab., 2006, 8, 508-516.

23. Tully, D. C.; Liu, H.; Alper, P. B.; Chatterjee, A. K.; Epple, R.; Roberts, M. J.; Williams, J. A.; Nguyen, K. T.; Woodmansee, D. H.; Tumanut, C.; Li, J.; Spraggon, G.; Chang, J.; Tuntland, T.; Harris, J. L.; Karanewsky, D. S.; Bioorg. Med. Chem. Lett., 2006, 16, 1975-1980.

24. Chang, J.; Zhao, K.; Pan, S.; Tetrahedron Lett., 2002, 43, 951-954.

25. Terashima, M.; Ishii, M.; Kanaoka, Y.; Synt., 1982, 484-485.

26. (a) Pottorf, R. S.; Chadha, N. K.; Katkevics, M.; Ozola, V.; Suna, E.; Ghane, H.; Regberg, T.; Player, M. R.; Tetrahedron Lett., 2003, 44, 175-178. (b) Zhang, Y.; Ji, M.; Eur. J. Chem., 2019, 45(8), 7506-7510. (c) Tang, Y.; Li, M.; Gao, H.; Rao, G.; Mao, Z.; RSC Adv., 2020, 10, 14317-14321

27. Osowska, K.; Miljanic, O. S.; J. Am. Chem. Soc., 2011, 133(4), 724-727.

28. Baltork, I. M.; Moghadam, M.;Tangestaninejad, S.; Mirkhani, V.; Zolfigol, M. A.; Hojati, S. F.; J. Iran. Chem. Soc., 2008, 5, 65-70.

29. Kumar, D.; Rudrawar, S.; Chakraborti, A. K. Aust. J. Chem., 2008, 61, 881-887.

30. Praveen, C.; Kumar, K. H.; Muralidharan, D.; Perumal, P.T. Tetrahedron., 2008, 64, 2369-2374.

31. Ravi, K. K.; Satyanarayana, P. V. V.; Srinivasareddy, B.; Der Pharma. Chemica., 2012, 4, 761-766.

32. Nagawade, R. R.; Shinde, D. B.; Chin. Chem. Lett., 2006, 17, 453-456.

33. Nadaf, R. N.; Siddiqui, S. A.; Daniel, T.; Lahoti, R. J.; Srinivasan, K.V.; J. Mol. Catal. A Chem., 2004, 214, 155-159.

34. Deluca, M. R.; Kerwin, S. M.; Tetrahedron., 1997, 53(2), 457-464. 
35. Goldstein, S.W.; Dambek, P. J.; J. Heterocyclic Chem., 1990, 27, 335-336.

36. Nakagawa, K.; Onoue, H.; Sugita, J.; Chem. Pharm. Bull., 1964, 12, 1135-1138.

37. Wang, B.; Zhang, Y.; Li, P.; Wang, L.; Chin. J. Chem., 2010, 28, 1697-1703.

38. Guru, M. M.; Ali, M. A.; Punniyamurthy, T.; Org. Lett., 2011, 13, 1194-1197.

39. Varma, R. S.; Kumar, D. J.; Heterocycl. Chem., 1998, 35, 1539-1540.

40. Stephens, F. F.; Bower, J. D.; J. Chem. Soc., 1949, 2971-2972.

41. Baltork, I. M.; Khosropour, A. R.; Hojati, S.F.; Catal. Commun., 2007, 8, 1865-1870.

42. Zhu, X.; Wei, Y.; Heterocycl. Commun., 2012, 18(4), 211-214.

43. (a) Chang, J.; Zhao, K.; Pan, S.; Tetrahedron Lett., 2002, 43, 951-954. (b) Varma, R. S.; Saini, R. K.; Prakash, O.; Tetrahedron Lett., 1997, 38, 2621-2622. (c) Park, K. H.; Jun, K.; Shin, S, R.; Oh, S. W.; Tetrahedron Lett., 1996, 37, 8869-8870. (d) Orjales, A.; Bordell, M.; Rubio, V.; J. Heterocyclic Chem., 1995, 32, 707. (e) Kozlov, N. S.; Kiselev, B. I.; Uch. Zap. Perm. Gas. Pedagog Inst., 1965, 32, 21-26. (f) Braz, G. I.; Myasnikova, G.V.; Yakubovich, A.Y.; Bazov V.P.; Kardash, I. K.; Pravednikov, A. N.; Khimiya Geterotsiklicheskikh Soedinenii., 1967, 2, 215-219.

44. (a) Bhawal, B. M.; Mayabhate, S. P.; Likhite, A. P.; Deshmukh, A. S.; Synthetic Commun., 1995, 25(21), 3315-3321. (b) Wang, F.; Hauske, J. R.; Clayton, T.; Chrusciel, A. R.; Solid Phase Organic Synthesis., 2001, 1, 73-84. (c) So, Y. H.; Zaleski, J. M.; Murlick, C.; Ellaboudy, A.; Macromolecules., 1996, 29, 2783-2795.

45. (a) Mukhopadhyay, C.; Datta, A.; Banik, B. K.; Heterocycles., 2007, 71(1), 181 (b) Mukhopadhyay, C.; Tapaswi, P. K.;
Tetrahedron Lett., 2008, 49, 6237-6240. (c) Makhopadhyay, C.; Datta, A.; J. Het.Chem., 2009, 46, 91-95. (d) Datta, A., Halder, S.; Orient. J. Chem., 2020, 36(6), 1218-1224.

46. Zhang, M.; Zhang, S.; Liu, M.; Cheng, J.; Chem. Commun., 2011, 47, 11522.

47. Guru, M. M.; Ashif, A.; Punniyamurthy, T.; J. Org. Chem., 2011, 76, 5295-5308.

48. Wang, B.; Zhang, Y.; Li, P.; Wang, L.; Chin. J. Chem., 2010, 28, 1697-1701.

49. Kawashita, Y.; Nakamichi, N.; Kawabata, H.; Hayashi, M.; Org. Lett., 2003, 5, 3713-3715.

50. Hilborn, J. G.; Labadie, J. W.; Hedrick, J. L.; Macromolecules., 1990, 23, 2854-2861.

51. Bonnamour, J.; Bolm, C.; Org. Lett., 2008, 10, 2665-2667.

52. Corsano, S.; Strappaghetti, G.; Castagnino, E.; Arch. Pharm., 1987, 320, 1118.

53. Wagner, G.; Eppner, B.; Pharmazie., 1980, 35, 285.

54. Evindar, G.; Batey, R. A.; J. Org. Chem., 2006, 71(5), 1802-1808.

55. Teo, Y. C.; Riduan, S. N.; Zhang, Y.; Green chem., 2013, 15, 2365.

56. Mayo, M. S.; Yu, X.; Zhou, X.; Feng, X.; Yamamoto, Y.; Bao, M.; J Org Chem., 2014, 79(13), 6310-6314.

57. Koleda, O.; Broese, T.; Noetzel, J.; Roemelt, M.; Suna, E.; Francke, R.; J. Org. Chem., 2017, 82, 11669-11681.

58. Chang, W.; Sun, Y.; Huang, Y.; Heteroat. Chem., 2017, 28, 21360.

59. Raminenia, S.; Kannasanib, R.K.; Satyanarayana, V. V.; Green Chem Lett Rev., 2014, 7(1), 85-89.

60. Kumar, D.; Rudrawar, S.; Chakraborti,.A. K.; Aust. J. Chem., 2008, 61, 881-887.

61. Zhu, X.; Wei, Y.; Heterocycl. Commun., 2012, 18(4), 211-214.

62. Maddila, S.; Jonnalagadda, S. B.; J. Chil. Chem. Soc., 2012, 57(2), 1099-1100. 